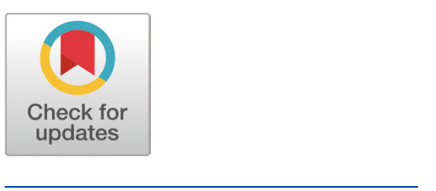

Received: Oct 15, 2019

Revised: Dec 24, 2019

Accepted: Dec 26, 2019

\#These authors contributed equally to this work.

*Corresponding author

Minho Song

Division of Animal and Dairy Science,

Chungnam National University,

Daejeon 34134, Korea.

Tel: +82-42-821-5776

E-mail: mhsong@cnu.ac.kr

Hyeun Bum Kim

Department of Animal Resources

Science, Dankook University, Cheonan

31116 , Korea.

Tel: +82-41-550-3653

E-mail: hbkim@dankook.ac.kr

Copyright $\odot 2020$ Korean Society of Animal Sciences and Technology.

This is an Open Access article distributed under the terms of the Creative Commons Attribution Non-Commercial License (http:// creativecommons.org/licenses/bync/4.0/) which permits unrestricted non-commercial use, distribution, and reproduction in any medium, provided the original work is properly cited.

ORCID

Sangwoo Park

https://orcid.org/0000-0003-2288-1374 Jeong Jae Lee

https://orcid.org/0000-0002-3455-0102

Boung Mo Yang

https://orcid.org/0000-0001-5635-6450

\section{Dietary protease improves growth performance, nutrient digestibility, and intestinal morphology of weaned pigs}

\author{
Sangwoo Park" ${ }^{1 \#}$, Jeong Jae Lee ${ }^{1 \#}$, Boung Mo Yang ${ }^{1 \#, ~ J i n ~ H o ~ C h o ~}{ }^{2 \#}$, Soyun Kim", \\ Joowon Kang ${ }^{1}$, Sejong $\mathrm{Oh}^{3}$, Dong-Jun Park ${ }^{4}$, Rider Perez-Maldonado ${ }^{5}$, \\ Jee-Yeon $\mathrm{Cho}^{6}$, Il-Hun Park ${ }^{6}$, Hyeun Bum Kim ${ }^{7 *}$ and Minho Song ${ }^{1 *}$ \\ ${ }^{1}$ Division of Animal and Dairy Science, Chungnam National University, Daejeon 34134, Korea \\ ${ }^{2}$ Division of Food and Animal Science, Chungbuk National University, Cheongju 28644, Korea \\ ${ }^{3}$ Department of Animal Science, Chonnam National University, Gwangju 61186, Korea \\ ${ }^{4}$ Korea Food Research Institute, Wanju 55365, Korea \\ ${ }^{5}$ DSM Nutritional Products Asia Pacific, Mapletree Business City 117440, Singapore \\ ${ }^{6}$ DSM Nutrition Korea Ltd., Seoul 06675, Korea \\ ${ }^{7}$ Department of Animal Resources Science, Dankook University, Cheonan 31116, Korea
}

\section{Abstract}

This study was conducted to evaluate effects of dietary protease (PR) on growth performance, nutrient digestibility, and intestinal morphology of weaned pigs. A total of 75 weaned pigs $[7.06 \pm$ $0.18 \mathrm{~kg}$ of average body weight (BW); 28 day old] were randomly allotted to 3 dietary treatments in a randomized complete block design (blocks = BW and sex): a diet based on corn and soybean meal to meet the requirement of crude protein (CP) as a positive control (PC; $C P=24.49 \%$ ), a low protein diet as a negative control $(\mathrm{NC} ; \mathrm{CP}=22.51 \%)$, and $\mathrm{NC}+0.02 \% \mathrm{PR}$. The PR used in this study was a commercial product containing 75,000 protease units/g derived from Nocardiopsis prasina produced in Bacillus licheniformis. Pigs were fed the dietary treatments for 6 weeks and the diets containing $0.2 \%$ chromic oxide for the last week of this study. Blood, feces, ileal digesta, and ileum samples were collected from randomly selected two pigs in each pen on respective time points. Measurements were growth performance, apparent ileal digestibility (AID) and apparent total tract digestibility (ATTD) of dry matter (DM), CP, and energy, frequency of diarrhea, packed cell volume (PCV), and ileal morphology of weaned pigs. Pigs fed PC and PR had higher $(p<0.05)$ final $B W$, average daily gain (ADG), and gain to feed ratio $(G: F)$ during overall experimental period than those fed NC. Pigs fed PC and PR had higher $(p<0.05)$ AID or ATTD of DM, $\mathrm{CP}$, or energy than those fed NC. Moreover, pigs fed PR had higher ratio between villus height and crypt depth $(p<0.05)$ and number of goblet cells $(p<0.05)$ than those fed NC. Addition of PR decreased $(p<0.05)$ frequency of diarrhea for the first two weeks after weaning compared with PC and NC. In addition, pigs fed PR had lower $(p<0.05)$ PCV on d 14 after weaning than those fed PC and NC. In conclusion, addition of PR in nursery diets with a low protein level significantly improved growth performance, nutrient digestibility, and intestinal morphology of weaned pigs.

Keywords: Growth performance, Intestinal morphology, Nutrient digestibility, Protease, Weaned pigs 
Jin Ho Cho

https://orcid.org/0000-0001-7151-0778

Soyun Kim

https://orcid.org/0000-0002-9845-2368

Joowon Kang

https://orcid.org/0000-0001-7340-1479

Sejong Oh

https://orcid.org/0000-0002-5870-3038

Dong-Jun Park

https://orcid.org/0000-0001-9452-9391

Rider Perez-Maldonado

https://orcid.org/0000-0001-7695-5258

Jee-Yeon Cho

https://orcid.org/0000-0002-7067-1841

II-Hun Park

https://orcid.org/0000-0003-0851-4180

Hyeun Bum Kim

https://orcid.org/0000-0003-1366-6090

Minho Song

https://orcid.org/0000-0002-4515-5212

\section{Competing interests}

No potential conflict of interest relevant to

this article was reported.

Funding sources

This work was supported by the National Research Foundation of Korea(NRF) grant funded by the Korea government(MSIT) (No. NRF-2019R1F1A1059662) and supported by DSM Nutrition Korea Ltd., Seoul, Korea.

Acknowledgements

Not applicable.

Availability of data and material Upon reasonable request, the datasets of this study can be available from the corresponding author.

Authors' contributions

Conceptualization: Cho JH, Song M.

Data curation: Kim HB, Song M.

Formal analysis: Cho JY, Perez-Maldonado R.

Methodology: Yang BM, Park IH.

Software: Oh S, Park DJ.

Validation: Lee JJ, Kim S.

Investigation: Park S, Yang BM, Kang J.

Writing - original draft: Park S, Lee JJ, Park $\mathrm{IH}$, Song $\mathrm{M}$.

Writing - review \& editing: Park S, Cho JH, Song M.

Ethics approval and consent to participate The protocol for this experiment was reviewed and approved by the Institutional Animal Care and Use Committee of Chungnam National University, Daejeon, Korea (approval code: CNU-00611).

\section{INTRODUCTION}

Soybean meal (SBM) is a major protein source in swine diets due to its excellent balance of amino acid such as lysine, threonine, tryptophan, and others. [1]. In general, SBM is the by-product of whole or dehulled soybeans after extraction of soy oil and contains approximately $44 \%-48 \%$ of crude protein $(\mathrm{CP})[2,3]$. However, SBM contains relatively high contents of anti-nutritional factors (ANFs) including protease inhibitors, allergens, lectins, phytoestrogens, oligosaccharedses, and phytin. [3-5]. Especially, the protease inhibitors reduce protein availability in the gastrointestinal tract of pigs because they bind and inactivate trypsin and chymotrypsin digestive enzymes [6]. These ANFs also have negative effects on utilization of dietary proteins and the health of pigs $[7,8]$.

Addition of exogenous enzymes in animal diets has being successfully used to improve the availability of nutrients and to reduce feed costs in the animal industry [9]. Dietary protease (PR) is an exogenous enzyme able to degrade proteins and has being widely used in swine diets as a part of multi-enzyme products [10]. Several studies have reported supplementation of enzyme cocktails with protease in swine diets enhanced protein digestion and growth performacnce of weaning, growing, and finishing pigs [11-13]. Recent studies also reported addition of PR alone in swine diets impoved gut development and health of weaned pigs by breaking down protein-bound complexes with other ANFs and affected positively nutrient digestibility and growth performace of pigs [9,11-15]. However, there was limited information about effects of PR when given alone in swine diets. Therefore, the main objectives of this study were to investigate effects of PR on growth performance, nutrient digestibility, and intestinal morphology of weaned pigs.

\section{MATERIALS AND METHODS}

The protocol for this experiment was reviewed and approved by the Institutional Animal Care and Use Committee of Chungnam National University, Daejeon, Korea. This experiment was conducted at the Animal Research Center of Chungnam National University.

\section{Experimental design, animals, and diets}

A total of 75 weaned pigs [Duroc $\times$ (Landrace $\times$ Yorkshire); $7.06 \pm 0.18 \mathrm{~kg}$ of initial body weight (BW); 28 day old] were randomly assigned to 3 dietary treatments (5 pigs with 3 barrows and 2 gilts per pen and 5 replicated pens per treatment) in a randomized completely block design (block = BW and sex). The dietary treatments were 1) a diet based on corn and SBM to meet or exceed the requirement of $\mathrm{CP}$ as a positive control ( $\mathrm{PC} ; \mathrm{CP}=24.49 \%), 2)$ a low protein diet as a negative control (NC; $\mathrm{CP}=22.51 \%)$, and 3$) \mathrm{NC}+0.02 \%$ protease (PR) ([2]; Table 1). The PR used in this study was a commercial product (Ronozyme ${ }^{\circledR}$ ProAct, DSM nutrition products, Kaiseraugst, Switzerland) containing 75,000 protease units/g derived from Nocardiopsis prasina produced in Bacillus licheniformis. The dietary treatments did not include animal plasma, antibiotics, or zinc oxide to avoid their antibacterial or physiological effects. Pigs were fed respective dietary treatments for 6 weeks. All pigs were housed in an environmentally controlled room with a slatted plastic floor and allowed ad libitum access to diets and water throughout the entire experiment period.

\section{Data and sample collection}

Individual pigs and amount of feed additions and refusals in each pen were weighed and recorded to measure average daily gain (ADG), average daily feed intake (ADFI), and ratio between ADG and ADFI (G:F) of pigs. Diarrhea of each pig was checked and its visual score was recorded by 3 independent evaluators with a score from 1 to 5 ( 1 = normal hard feces; 2 = slightly soft feces; $3=$ 
Table 1. Composition of basal diet for weaned pigs (as-fed basis)

\begin{tabular}{|c|c|c|}
\hline Items & PC & NC \\
\hline \multicolumn{3}{|l|}{ Ingredients (\%) } \\
\hline Corn & 56.09 & 58.09 \\
\hline Soybean meal (44\%) & 26.00 & 24.00 \\
\hline Soy protein concentrate & 12.00 & 12.00 \\
\hline Soybean oil & 3.00 & 3.00 \\
\hline Limestone & 1.30 & 1.30 \\
\hline Monocalcium phosphate & 1.20 & 1.20 \\
\hline Vitamin-mineral premix ${ }^{1)}$ & 0.04 & 0.04 \\
\hline L-Lysine- $\mathrm{HCl}$ & 0.24 & 0.24 \\
\hline DL-Methionine & 0.09 & 0.09 \\
\hline L-Threonine & 0.04 & 0.04 \\
\hline Total & 100 & 100 \\
\hline \multicolumn{3}{|c|}{ Calculated energy and nutrient contents } \\
\hline Metabolizable energy (Mcal/kg) & 3.53 & 3.42 \\
\hline Crud protein (\%) & 24.49 & 22.51 \\
\hline Calcium (\%) & 0.81 & 0.73 \\
\hline Phosphorus (\%) & 0.69 & 0.63 \\
\hline Lysine (\%) & 1.54 & 1.41 \\
\hline \multicolumn{3}{|c|}{$\begin{array}{l}\text { 'The vitamin-mineral premix provided the following quantities of vitamins per kilogram of diet: vitamin } \mathrm{A}, 12,000 \mathrm{IU} \text {; vitamin } \mathrm{D}_{3} \text {, } \\
2,500 \mathrm{IU} \text {; vitamin } \mathrm{E}, 30 \mathrm{IU} \text {; vitamin } \mathrm{K}_{3}, 3 \mathrm{mg} \text {; D-pantothenic acid, } 15 \mathrm{mg} \text {; nicotinic acid, } 40 \mathrm{mg} \text {; choline, } 400 \mathrm{mg} \text {; and vitamin } \mathrm{B}_{12} \text {, } \\
12 \mathrm{\mu g} \text {; Fe, } 90 \mathrm{mg} \text { from iron sulfate; } \mathrm{Cu}, 8.8 \mathrm{mg} \text { from copper sulfate; } \mathrm{Zn}, 100 \mathrm{mg} \text { from zinc oxide; } \mathrm{Mn}, 54 \mathrm{mg} \text { from manganese } \\
\text { oxide; I, } 0.35 \mathrm{mg} \text { from potassium iodide; } \mathrm{Se}, 0.30 \mathrm{mg} \text { from sodium selenite. }\end{array}$} \\
\hline
\end{tabular}

soft, partially formed feces; 4 = loose, semi-liquid feces; and 5 = watery, mucous-like feces) each day for the first 2 weeks of this experiment [16]. Frequency of diarrhea was calculated by counting pen days with average diarrhea score from individual pigs in each pen of 4 or greater [17,18]. Whole blood samples were collected from the jugular vein of randomly selected 2 pigs in each pen using EDTA tubes (Becton Dickinson Vacutainer Systems, Franklin Lakes, NJ, USA) containing anticoagulant on day 1, 3, 7, and 14 after weaning. For the last week of the experiment period, pigs were fed respective dietary treatments containing $0.2 \%$ chromic oxide as an indigestible marker. Fecal samples were collected from randomly selected 2 pigs in each pen by rectal palpation daily for the last 3 days after the 4-d adjustment period. The collected fecal samples were pooled and stored at $-20^{\circ} \mathrm{C}$ until analysis. Diet samples were also collected and stored at $-20^{\circ} \mathrm{C}$ until analysis. Randomly selected 2 pigs in each pen were anesthetized by an intra-muscular injection of a 2-mL suxamethonium chloride (Succicholine ${ }^{\circledR}$, Ilsung Pharm. Co. Ltd., Seoul, Korea) at the end of this experiment. After anesthesia, pigs were euthanized by $\mathrm{CO}_{2}$ gas [19]. Ileal digesta samples were collected from distal ileum before the ileocecal junction [11]. The collected ileal digesta samples were stored at $-20^{\circ} \mathrm{C}$ until analysis. Sections of ileum of $3 \mathrm{~cm}$ length were collected, washed gently with distilled water, and fixed in $10 \%$ neutral buffered formalin for histological analysis [20,21].

\section{Sample analyses and measurements}

Whole blood samples were analyzed to measure packed cell volume (PCV) using a multi-parameter, automated hematology analyzer calibrated for porcine blood (scil Vet abc hematology analyzer, scil animal care company, F-67120 Altorf, France). Frozen ileal digesta and fecal samples were freeze-dried and finely ground through a cyclone mill (Foss Tecator Sycltec 1093, Hillerød, Den- 
mark) before chemical analysis. Diets, fecal samples, and ileal samples were analyzed for dry matter (DM; method 930.15), nitrogen (method 999.03) [22], gross energy using a bomb calorimeter (Parr 1281 Bomb Calorimeter, Parr Instrument Co., Moline, IL, USA), and chromium content using an absorption spectrophotometer (Hitachi Z-5000 Absorption Spectrophotometer, Hitachi High-Technologies Co., Tokyo, Japan) based on the report by Williams et al. [23]. The apparent ileal digestibility (AID) and apparent total tract digestibility (ATTD) of DM, CP, and energy were calculated for each diet according to Stein et al. [24]. The procedures for the measurement of intestinal morphology were based on the report by Liu et al. [20]. The fixed intestinal tissue samples were placed in paraffin, sliced at $5 \mu \mathrm{m}$, and stained with hematoxylin and eosin. The stained slides were scanned by fluorescence microscopy (TE2000, Nikon, Tokyo, Japan) with a charge-coupled device (CCD) camera (DS-Fi1; Nikon, Tokyo, Japan) to measure intestinal morphology such as villus height, width, and area, crypt depth, ratio between villus height and crypt depth (VH:CD), and number of goblet cells by selecting ten straight and integrated villi and their associated crypts and goblet cells. The fluorescent images were processed with NIS-Elements BR software 3.00 (Nikon, Japan).

\section{Statistical analyses}

Data were analyzed using the PROC GLM procedure of SAS (SAS Inst. Inc., Cary, NC, USA) in randomized complete block design. The experimental unit was the pen and blocks were BW and sex. The statistical model for growth performance, PCV, AID and ATTD, and number of goblet cells included effects of dietary treatments as a fixed effect and BW and sex as covariates. In addition, pair-wise comparisons were performed among dietary treatments when a main effect of diet was found. The chi-squared test was used for the frequency of diarrhea. Results are given as mean \pm SEM. Statistical significance and tendency were considered at $p<0.05$ and $0.05 \leq p<0.10$, respectively.

\section{RESULTS AND DISCUSSION}

Present study showed there were differences $(p<0.05)$ on ADG and G:F of weaned pigs during overall experimental period between PC and NC (Table 2). In addition, weaned pigs fed PR had higher ADG and G:F from d 1 to $7(p<0.05)$ and during overall experimental period $(p<0.05)$ than those fed NC (Table 2). However, no difference was found on growth performance of weaned pigs during overall experimental period between $\mathrm{PC}$ and $\mathrm{PR}$ (Table 2). These results are similar to the results from previous studies for weaned pigs [10,11,21] and for growing pigs [14,25]. The reason for these observations may be related to the improved nutrient utilization efficiency by addition of PR [25]. However, some studies reported that no positive effects were found on growth performance of growing-finishing pigs by addition of PR $[13,26]$, maybe because of different growth stages of the pigs with different digestive systems [10].

In the present study, there were differences $(p<0.05)$ on AID of DM, CP, and energy of weaned pigs between PC and NC (Fig. 1). However, no differences were found on nutrient AID of weaned pigs between PC and PR (Fig. 1). Similar patterns were found $(p<0.05)$ on ATTD for DM and $\mathrm{CP}$, but not for energy, compared with the results of nutrient AID (Fig. 2). The improved nutrient digestibility in this study was similar to results reported by previous studies [11,27,28]. Addition of exogenous enzymes in non-ruminant diets has been using for several benefits including, minimization of anti-nutritional effects and maximization of nutrient utilization, to improve nutrient utilization and growth performance of non-ruminants [29] because the digestive system and the secretion and activity of digestive enzymes of young non-ruminants are immature and insufficient 
Table 2. Effects of dietary protease on growth performance of weaned pigs ${ }^{1)}$

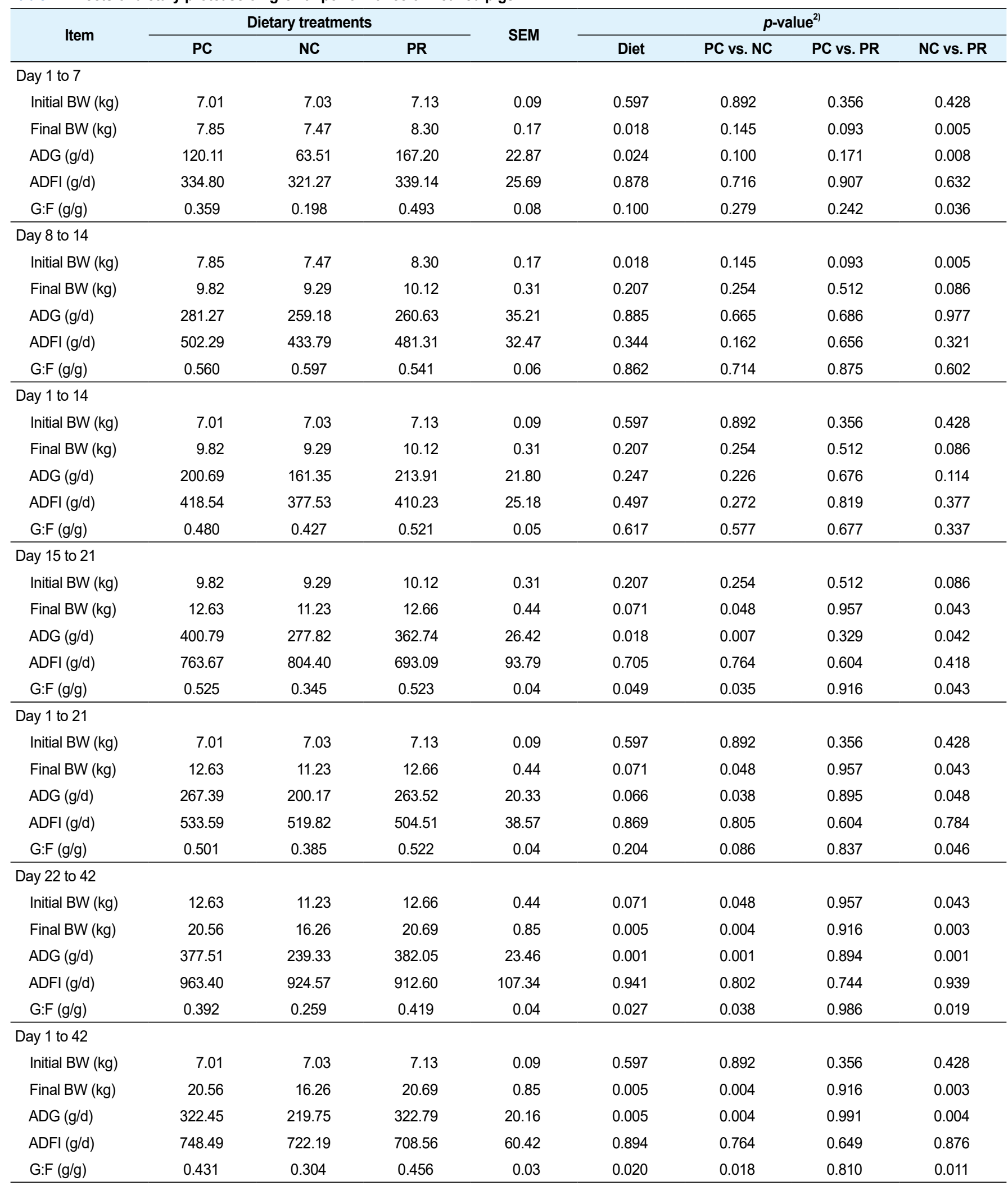

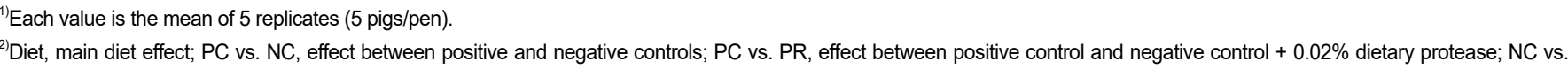
$\mathrm{PR}$, effect between negative control and negative control $+0.02 \%$ dietary protease.

PC, positive control with required level of protein; $\mathrm{NC}$, negative control with low level of protein; PR, negative control $+0.02 \%$ dietary protease; BW, body weight; $A D G$, average daily gain; ADFI, average daily feed intake; G:F, gain to feed ratio; SEM, standard error of means. 


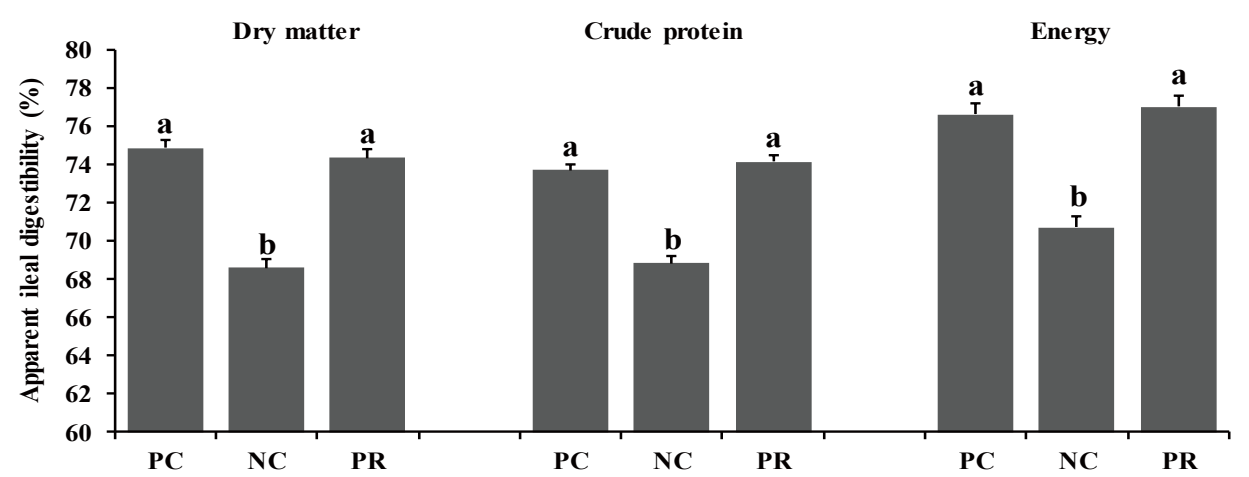

Fig. 1. Effects of dietary protease on apparent ileal digestibility of weaned pigs. Each value is the mean of 5 replicates. ${ }^{a, b}$ Means with different letters within each variable differ $(p<0.05)$. PC, positive control with required level of protein; NC, negative control with low level of protein; PR, negative control $+0.02 \%$ dietary protease.

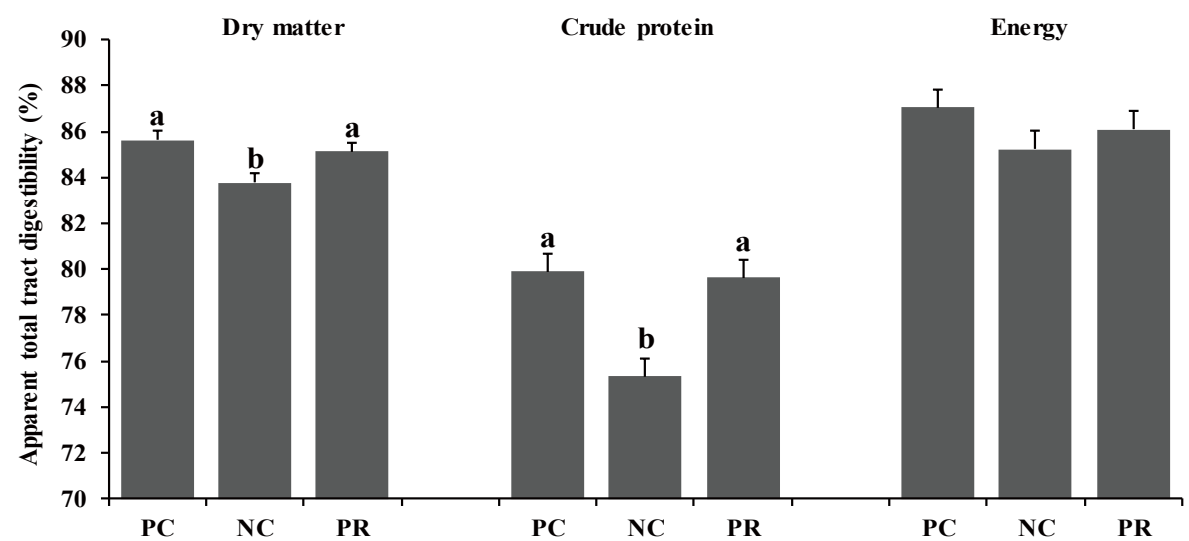

Fig. 2. Effects of dietary protease on apparent total tract digestibility of weaned pigs. Each value is the mean of 5 replicates. ${ }^{a, b}$ Means with different letters within each variable differ $(p<0.05)$. PC, positive control with required level of protein; NC, negative control with low level of protein; PR, negative control $+0.02 \%$ dietary protease.

to fully utilize nutrients efficiently $[29,30]$. Similarly, the addition of protease in weaned pig diets may improve their growth performance by increasing nutrient utilization $[10,25]$.

The VH:CD can be an indicator to evaluate nutrient digestion and absorption capacity of the small intestine [31]. The reduction of villus height could induce decreased absorption of nutrients, which may be responsible for the reduced growth performance. The present study showed weaned pigs fed PR had higher VH:CD $(p<0.05)$ in ileum than those fed NC (Table 3). This result is similar to the result reported by previous studies [12,32]. It may be possible the addition of PR may reduce allergenic reactions that are derived from feeding SBM and that can cause intestinal damage $[32,33]$.

Diarrhea and infectious disease are serious problems around weaning and usually lead to an impaired growth performance and increased mortality of weaning pigs [34]. However during this study PR treatment showed a reduced $(p<0.05)$ frequency of diarrhea for the first 2 weeks after weaning (Fig. 3) and PCV on d 14 (Fig. 4) with an increased $(p<0.05)$ number of goblet cells (Fig. 5) compared with the $\mathrm{NC}$ and/or PC. Previous studies have also reported that supplementation of dietary enzymes can reduce diarrhea of pigs. This beneficial effect, maybe attributed to the develop- 
Table 3. Effects of dietary protease on ileal morphology of weaned pigs ${ }^{1)}$

\begin{tabular}{|c|c|c|c|c|c|c|c|c|}
\hline \multirow{2}{*}{ Item } & \multicolumn{3}{|c|}{ Dietary treatments } & \multirow{2}{*}{ SEM } & \multicolumn{4}{|c|}{$p$-value ${ }^{2)}$} \\
\hline & PC & NC & PR & & Diet & PC vs. NC & PC vs. PR & NC vs. PR \\
\hline Villus height $(\mu \mathrm{m})$ & 312.52 & 282.70 & 318.23 & 11.69 & 0.110 & 0.097 & 0.736 & 0.053 \\
\hline Crypt depth $(\mu \mathrm{m})$ & 102.32 & 99.15 & 88.48 & 5.37 & 0.204 & 0.684 & 0.094 & 0.186 \\
\hline $\mathrm{VH}: \mathrm{CD}$ & 3.11 & 2.87 & 3.67 & 0.24 & 0.099 & 0.507 & 0.130 & 0.040 \\
\hline Villus width $(\mu \mathrm{m})$ & 101.72 & 93.59 & 98.82 & 4.23 & 0.414 & 0.200 & 0.649 & 0.391 \\
\hline Villus area $\left(\mu \mathrm{m}^{2}\right)$ & 24,938 & 23,536 & 23,815 & 2,064 & 0.880 & 0.640 & 0.707 & 0.925 \\
\hline
\end{tabular}

${ }^{1)}$ Each value is the mean of 5 replicates ( 5 pigs/pen).

${ }^{2)}$ Diet, main diet effect; PC vs. NC, effect between positive and negative controls; PC vs. PR, effect between positive control and negative control + $0.02 \%$ dietary protease; NC vs. $\mathrm{PR}$, effect between negative control and negative control $+0.02 \%$ dietary protease.

$\mathrm{PC}$, positive control with required level of protein; NC, negative control with low level of protein; PR, negative control $+0.02 \%$ dietary protease; $V H$, villus height; CD, crypt depth; SEM, standard error of means.

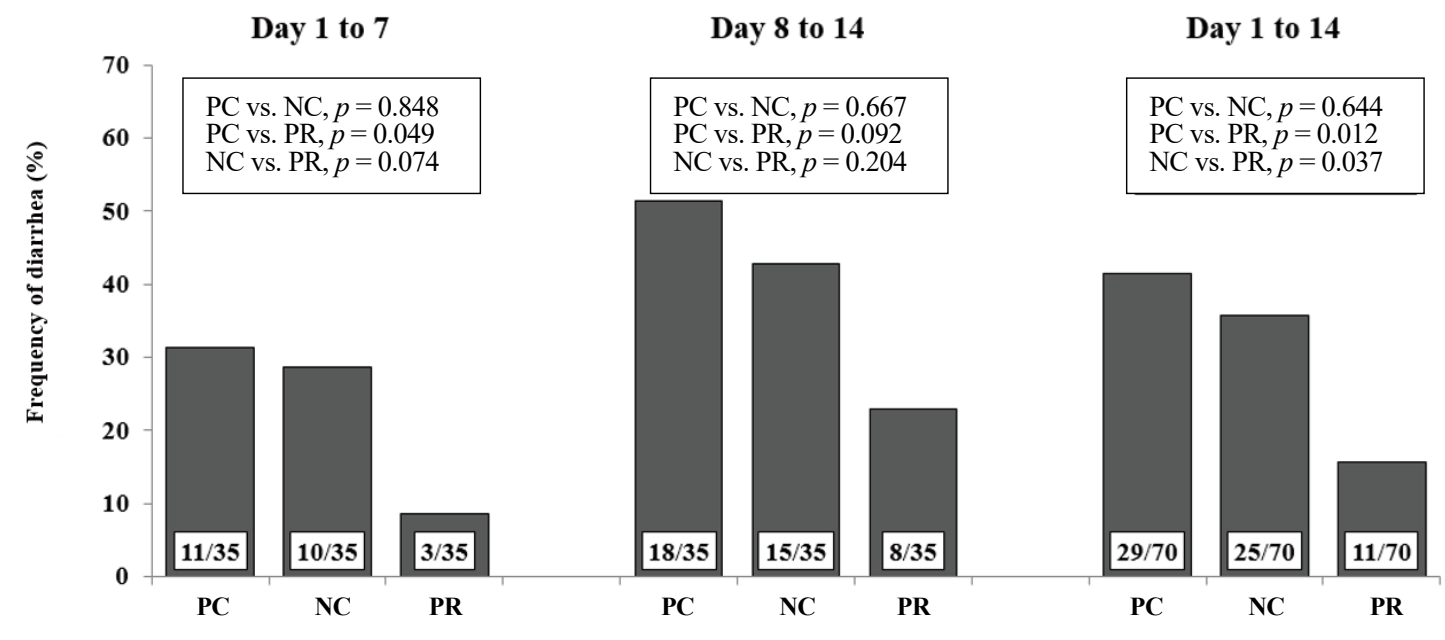

Fig. 3. Effects of dietary protease on frequency of diarrhea of weaned pigs for the first 2 weeks after weaning. Number of diarrhea out of number of pen days is presented in each bar. Frequency of diarrhea $(\%)=\left(\right.$ number of diarrhea / number of pen days) $\times 100$. Data was analyzed by the $\chi^{2}$ test. Three, four, and one pigs were removed from PC, NC, and PR, respectively (there were no differences among dietary treatments). PC, positive control with required level of protein; $\mathrm{NC}$, negative control with low level of protein; PR, negative control $+0.02 \%$ dietary protease.

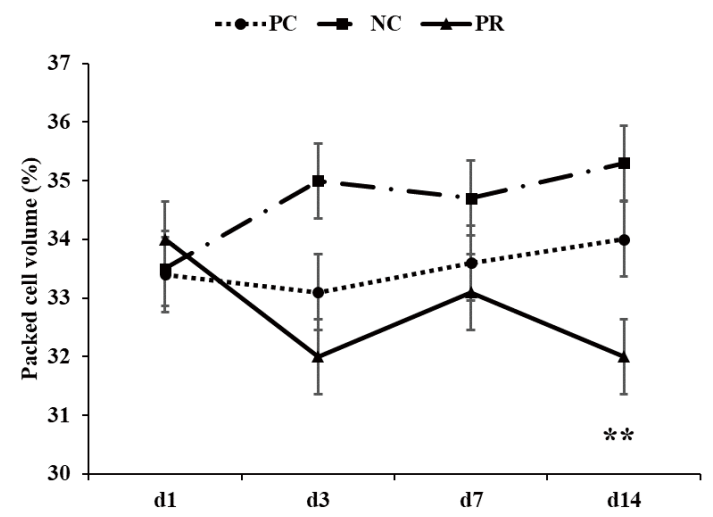

Fig. 4. Effect of dietary protease on packed cell volume of weaned pigs. Each value is the mean of 5 replicates. **Different between PC, NC, and PR $(p<0.05)$. PC, positive control with required level of protein; NC, negative control with low level of protein; PR, negative control $+0.02 \%$ dietary protease.

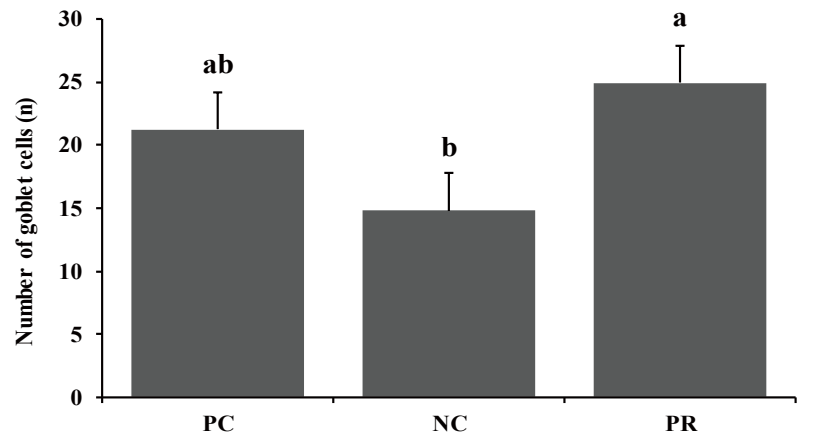

Fig. 5. Effect of dietary protease on number of goblet cells of weaned pigs. Each value is the mean of 5 replicates. ${ }^{a, b}$ Means with different letters within each variable differ $(p<0.05)$. PC, positive control with required level of protein; NC, negative control with low level of protein; PR, negative control $+0.02 \%$ dietary protease. 
ment of the digestive tract, the increase of enzyme activity in the digestive system, and the improvement of nutrient digestibility $[10,35]$.

\section{CONCLUSION}

In conclusion, addition of PR in nursery diets with a low protein level improved growth performance, nutrient digestibility, and intestinal morphology of weaned pigs.

\section{REFERENCES}

1. Kim S, Kim B, Kim Y, Jung S, Kim Y, Park J, et al. Value of palm kernel co-products in swine diets. Korean J Agric Sci. 2016;43:761-8.

2. National Research Council. Nutrient requirements of swine. 11th ed. Washington, DC: The National Academies Press; 2012.

3. Pettersson D, Pontoppidan K. Soybean meal and the potential for upgrading its feeding value by enzyme supplementation. In: El-Shemy H, editor. Soybean: bio-active compounds. London: IntechOpen; 2013. p. 288-307.

4. DiPietro CM, Liener IE. Heat inactivation of the kunitz and bowman-birk soybean protease inhibitors.J Agric Food Chem. 1989;37:39-44.

5. Liener IE. Implications of antinutritional components in soybean foods. Crit Rev Food Sci Nutr. 1994;34:31-67.

6. Sklan D, Hurwitz S, Budowski P, Ascarelli I. Fat digestion and absorption in chicks fed raw or heated soybean meal.J Nutr. 1975;105:57-63.

7. Friedman M, Brandon DL. Nutritional and health benefits of soy proteins. J Agric Food Chem. 2001;49:1069-86.

8. Jo JK, Ingale SL, Kim JS, Kim YW, Kim KH, Lohakare JD, et al. Effects of exogenous enzyme supplementation to corn- and soybean meal-based or complex diets on growth performance, nutrient digestibility, and blood metabolites in growing pigs.J Anim Sci. 2012:90:3041-8.

9. Adeola $\mathrm{O}$, Cowieson AJ. Opportunities and challenges in using exogenous enzymes to improve nonruminant animal production. J Anim Sci. 2011;89:3189-218.

10. Zuo J, Ling B, Long L, Li T, Lahaye L, Yang C, et al. Effect of dietary supplementation with protease on growth performance, nutrient digestibility, intestinal morphology, digestive enzymes and gene expression of weaned piglets. Anim Nutr. 2015;1:276-82.

11. Kim Y, Baek J, Jang K, Kim J, Kim S, Mun D, et al. Effects of dietary enzyme cocktail on growth performance, intestinal morphology, and nutrient digestibility of weaned pigs. Korean J Agric Sci. 2017;44:513-8.

12. Wang D, Zeng Z, Piao X, Li P, Xue L, Zhang Q, et al. Effects of keratinase supplementation of corn-soybean meal based diets on apparent ileal amino acid digestibility in growing pigs and serum amino acids, cytokines, immunoglobulin levels and loin muscle area in nursery pigs. Arch Anim Nutr. 2011;65:290-302.

13. Min Y, Choi Y, Kim Y, Jeong Y, Kim D, Kim J, et al. Effects of protease supplementation on growth performance, blood constituents, and carcass characteristics of growing-finishing pigs. J Fish Biol. 2019;61:234-8.

14. Min Y, Choi Y, Choe J, Kim Y, Jeong Y, Kim D, et al. Effects of dietary mixture of protease and probiotics on growth performance, blood constituents, and carcass characteristics of growing-finishing pigs.J Anim Sci Technol. 2019;61:272-7.

15. Prykhodko O, Pierzynowski SG, Nikpey E, Sureda EA, Fedkiv O, Westrom BR. Pancreatic 
and pancreatic-like microbial proteases accelerate gut maturation in neonatal rats. PloS ONE. 2015;10:e0116947.

16. Min YJ, Kim JS, Kim SA, Jang KB, Mun DY, Kim BH, et al. Effects of eco-friendly multi-enzyme on diarrhea and immune response of weaned pigs. Korean J Org Agric. 2018;26:151-61.

17. Kim J, Seo J, Kim W, Yun HM, Kim SC, Jang Y, et al. Effects of palm kernel expellers on productive performance, nutrient digestibility, and white blood cells of lactating sows. Asian-Australas J Anim Sci. 2015;28:1150-4.

18. Kim S, Kim B, Kim Y, Jung S, Kim Y, Park J, et al. Value of palm kernel co-products in swine diets. Korean J Agric Sci. 2016;43:761-8.

19. Rault JL, McMunn KA, Marchant-Forde JN, Lay DC. Gas alternatives to carbon dioxide for euthanasia: a piglet perspective. J Anim Sci. 2013;91:1874-83.

20. Liu Y, Song M, Che TM, Almeida JAS, Lee JJ, Bravo D, et al. Dietary plant extracts alleviate diarrhea and alter immune responses of weaned pigs experimentally infected with a pathogenic Escherichia coli.J Anim Sci. 2013;91:5294-306.

21. Kim SK, Cho MW, Kim JS, Jang KB, Kim SA, Mun DY, et al. Effects of eco-friendly multi-enzyme on growth performance, intestinal morphology, and nutrient digestibility of weaned pig. Korean J Org Agric. 2018;26:141-9.

22. AOAC [Association of Official Analytical Chemists] International. Official methods of analysis of AOAC International. Gaithersburg, MD: AOAC International; 2005.

23. Williams $\mathrm{CH}$, David DJ, lismaa $\mathrm{O}$. The determination of chromic oxide in faeces samples by atomic absorption spectrophotometry.J Agric Sci. 1962;59:381-5.

24. Stein HH, Seve B, Fuller MF, Moughan PJ, de Lange CF. Invited review: amino acid bioavailability and digestibility in pig feed ingredients: terminology and application. J Anim Sci. 2007;85:172-80.

25. Choe J, Kim KS, Kim HB, Park S, Kim J, Kim S, et al. Effects of protease on growth performance and carcass characteristics of growing-finishing pigs. S Afr J Anim Sci. 2017;47:697703.

26. O'Shea CJ, Mc Alpine PO, Solan P, Curran T, Varley PF, Walsh AM, et al. The effect of protease and xylanase enzymes on growth performance, nutrient digestibility, and manure odour in grower-finisher pigs. Anim Feed Sci Technol. 2014;189:88-97.

27. Yu B, Wu ST, Liu CC, Gauthier R, Chiou PWS. Effects of enzyme inclusion in a maize-soybean diet on broiler performance. Anim Feed Sci Technol.2007;134:283-94.

28. Pan L, Zhao PF, Yang ZY, Long SF, Wang HL, Tian QY, et al. Effects of coated compound proteases on apparent total tract digestibility of nutrients and apparent ileal digestibility of amino acids for pigs. Asian-Australas J Anim Sci. 2016;29:1761-7.

29. Hedemann MS, Jensen BB. Variations in enzyme activity in stomach and pancreatic tissue and digesta in piglets around weaning. Arch Anim Nutr. 2004;58:47-59.

30. Lalles JP, Boudry G, Favier C, Le Floc'h N, Luron I, Montagne L, et al. Gut function and dysfunction in young pigs: physiology. Anim Res. 2004;53:301-16.

31. Montagne L, Pluske JR, Hampson DJ. A review of interactions between dietary fibre and the intestinal mucosa, and their consequences on digestive health in young non-ruminant animals. Anim Feed Sci Technol. 2003;108:95-117.

32. Rooke JA, Slessor M, Fraser H, Thomson JR. Growth performance and gut function of piglets weaned at four weeks of age and fed protease-treated soya-bean meal. Anim Feed Sci Technol. 1998;70:175-90.

33. Chen F, Hao Y, Piao XS, Ma X, Wu GY, Qiao SY, et al. Soybean-derived $\beta$-conglycinin affects proteome expression in pig intestinal cells in vivo and in vitro. J Anim Sci. 2011;89:743- 
53.

34. Fairbrother JM, Nadeau E, Gyles CL. Escherichia coli in postweaning diarrhea in pigs: an update on bacterial types, pathogenesis, and prevention strategies. Anim Health Res Rev. 2005;6:17-39.

35. Heo JM, Opapeju FO, Pluske JR, Kim JC, Hampson DJ, Nyachoti CM. Gastrointestinal health and function in weaned pigs: a review of feeding strategies to control post-weaning diarrhoea without using in-feed antimicrobial compounds. J Anim Physiol Anim Nutr. 2013;97:207-37. 